\title{
DNA sexing for gender determination of Changeable Hawk- Eagle (Nisaetus cirrhatus, Gmelin, 1788)
}

\author{
Annisa $^{{ }^{*}}$, Mariana Fikriyanti ${ }^{1}$ and Susanti Withaningsih ${ }^{1,2,3}$ \\ ${ }^{1}$ Department Biology, Faculty of Mathematics and Natural Sciences Natural Science, Universitas Padjadjaran, Indonesia \\ ${ }^{2}$ Center for Environment and Sustainability Science, Universitas Padjadjaran, Indonesia \\ ${ }^{3}$ Environment Science and Sustainability Science Program, Postgraduate School, Universitas Padjadjaran, Indonesia
}

\begin{abstract}
The Changeable hawk-eagle (Brontok eagle) is a protected bird species. It is one of the most frequently hunted and traded birds in Indonesia. The processes of being traded changes this bird natural behaviour. Therefore, a rehabilitation effort to return the eagle's behaviour to conform to its natural habits is needed. The ultimate goal of rehabilitation is to release the changeable hawk-eagle back into its natural habitat. In conservation and breeding programs, efforts to determine the sex of eagles to be released are very important to help increase the population of changeable hawk-eagles in their habitat by looking at the sex ratio. At the present, sex determination at the Kamojang Conservation Eagle Center (Pusat Konservasi Elang Kamojang or PKEK) uses the morphometric method. This research used the DNA sexing method with primers $2550 \mathrm{~F}$ and 2718R to determine the sex of Changeable hawk-eagles in PKEK by extracting DNA from blood samples of 30 eagles. Comparison of DNA sexing results and morphometric data showed differences. This proves that DNA sexing, is suitable in determining changeable hawk-eagles' sex.
\end{abstract}

\section{Introduction}

Conservation in Indonesia is very important, especially as a country with the third highest mega biodiversity after Brazil and Zaire [1]. One of the conserved faunas is a bird of prey or commonly called a raptor. Raptors have a role as an umbrella species and several types of them act as keystone species. The role of raptors in nature is related to their existence, most of which are of rare status. Raptors are categorized as one of the species that are very sensitive to environmental change [2].

The Changeable hawk-eagle (Nisaetus cirrhatus) is a raptor of the Accipitridae family and one of the protected birds in Indonesia. These eagles are monomorphic birds, found in several major islands of Indonesia such as Sumatra, Java, Bali and the islands of Sulawesi [3]. The eagle is listed as a low-risk conservation status (Least Concern) according to IUCN (The International Union for Conservation of Nature); the category of Appendix II according to CITES (The Convention on International Trade in Endangered Species) and protected by the Indonesian government to guarantee its preservation in nature based on Law No.5 of 1990.

The Changeable hawk-eagle is a type of eagle that is often hunted and used as pets. Birds that are kept or traded, of course, must be released back into the wild. This is stated in the Republic of Indonesia Government Regulation No.7 of 1999. Birds to be released need to be rehabilitated as an effort to restore the eagle's behavior to conform to its habits in nature. One of the institutions that plays a role in re-introducing eagles into the wild is the Kamojang Eagle Conservation Center or Pusat Konservasi Elang Kamojang (PKEK).

Several steps need to be done in order to release back the eagle into the wild, which include: quarantine, observation, rehabilitation, habituation, and release of wild [4]. The rehabilitation process is an effort to restore the eagle's natural character to conform to its habits in nature, because of the animals that have been long maintained usually have a change in behavior when compared to animals in nature. Knowledge of the sex of eagles to be released is an important stage in the rehabilitation process. This is related to the importance of the sex ratio found in the environment where it was released. A balanced sex ratio in a small population is important for the management and conservation of threatened species. The success of correct gender identification will contribute to the success of these efforts [5]

According to [6], the sex ratio of a small and endangered population significantly has too many females or too many males in the population. An unbalanced sex ratio increases the negative effects of the allele effects (positive relationship between population density and growth rate), demographic problems, and may lead to extinction. Eagles are socially monogamous animals or birds that show loyalty to one partner. Therefore, a good sex ratio for eagles is 1: 1 [7].

Sex determination in eagles can be done by several methods such as laparoscopy, vent sexing, steroid sexing, morphometric measurements, and molecular sexing. Technological advances in the molecular field are an option that can be taken into account to determine the sex of birds. The molecular sexing technique is a quick option and requires only a small sample of DNA. Even though this technique is relatively expensive compare to morphometric, the molecular sexing technique assisted by Polymerase Chain Reaction (PCR) has a high sensitivity, so that the possibility of error is relatively small [8]. The gene that is often used for sexing is chromohelicase DNA binding gene (CHD).

\footnotetext{
*Corresponding author : annisa18040@mail.unpad.ac.id
} 
$C H D$ is a gender marker gene in Aves. $C H D$ genes are on the $\mathrm{Z}$ and $\mathrm{W}$ chromosomes, which consist of $C H D-Z$ (reside on the $\mathrm{Z}$ chromosome) and $C H D-W$ (located on the $\mathrm{W}$ chromosome) [9]. The $C H D$ gene band will be identified successfully if an appropriate and suitable primer is used. If the primers used do not match, the CHD gene band will not be visible on the visualization results with agarose gel. Sex determination was carried out based on the results of visualization of DNA amplification on agarose gel. The presence of a single DNA band indicates that the sample is male ( $\mathrm{ZZ}$ chromosome) and the presence of a double DNA band (ZW chromosome) indicates that the sample is female [10].

Morphometric measurements are usually carried out at the PKEK to find out physical data and as a method to determine the sex of the eagle to be rehabilitated. Measurement data that is usually taken are wing length, tail length, beak length, beak width, tarsus length, toes length, total head length, total length, and body weight. Other than that, the cloaca is a gender consideration. According to [11], the morphometric method has a low level of confidence if it is not supported by other data, especially when applied to monomorphic birds. This study aimed to confirm the results of the morphometrics measurements for sex determination with molecular sexing detection.

\section{Material and methods}

\subsection{DNA sampling}

Blood samples from 30 Changeable hawk-eagle (Nisaetus cirrhatus Gmelin, 1788) from PKEK, Garut West Java, Indonesia. DNA sexing was conducted at the Laboratory of Biosystematics and molecular, Department of Biology, Universitas Padjadjaran. The eagle must be calm during the blood draw. The blood was collected in the labelled EDTA tube and put into ice.

DNA was extracted with Geneaid GB100 Genomic DNA Mini Kit. DNA samples then quantitively measured using spectrophotometry for purity and concentration.

\subsection{DNA amplification}

The negative control used in the PCR process was sterile distillated water. The primers used were primers $2550 \mathrm{~F}$ / 2718R [12], with the order of bases: 2550F (GTTACTGATTCGTCTACGAGA) and 2718R (ATTGAAATGATCCAGTGCTTG). Each sample was subjected to three repetitions of PCR for consistency. The PCR mix used was GoTaq ${ }^{\circledR}$ Green Master Mix, with the composition and temperature cycle referring to [10] with modification. The PCR compositions used were DNA template $(20 \mathrm{ng} / \mu \mathrm{l})$, forward and reverse primer (@10 pmol), MgCl2 (25mM), 1X GoTaq ${ }^{\circledR}$ Green Master 2X PCR buffer Mix, and ddH2O to total volume of $25 \mu \mathrm{l}$. PCR was done 35 cycles with conditions: pre-denaturation $94{ }^{\circ} \mathrm{C}$ for $5 \mathrm{~min}$, denaturation $94^{\circ} \mathrm{C}$ for $20 \mathrm{~s}$, annealing $54{ }^{\circ} \mathrm{C}$ for 30 , extension $72{ }^{\circ} \mathrm{C}$ for $40 \mathrm{~s}$, and a final extension at $72{ }^{\circ} \mathrm{C}$ for $10 \mathrm{~min}$. Visualization of PCR results in electrophoresis using $1.5 \%$ agarose gel with $100 \mathrm{bp}$ DNA ladder (Promega). Agarose gel then then immersed in GelRed ${ }^{\circledR}$ Nucleic Acid Gel Stain and DNA bands were visualized under the UV transilluminator. DNA bands were measured with GelAnalyzer 2010a version software [13].

\subsection{Data analysis}

Based on the visualization of the CHD gene amplification products in all samples, it was shown by the presence of a single DNA band (CHD-Z) in males and the presence of two DNA bands (CHD-Z and CHD$\mathrm{W})$ in females [10]. The results of identification were written in the ratio females against males based on [14].

$$
R p=\frac{N_{\mathrm{FP}}}{N_{\mathrm{MP}}}=\frac{N_{\mathrm{F}}+N_{\mathrm{FJ}}}{N_{\mathrm{M}}+N_{\mathrm{MJ}}}
$$

$\mathrm{N}_{\mathrm{FP}}=$ the abundance of all females in the population

$\mathrm{N}_{\mathrm{MP}}=$ the abundance of all males in the population

$\mathrm{N}_{\mathrm{F}}=$ an abundance of adult females

$\mathrm{N}_{\mathrm{FJ}}=$ an abundance of juvenile females

$\mathrm{N}_{\mathrm{M}}=$ abundance of adult males

$\mathrm{N}_{\mathrm{MJ}}=$ an abundance of juvenile males

\section{Result and Discussion}

\subsection{DNA isolation and extraction}

The result of DNA extraction concentration ranged from $21.20 \mathrm{ng} / \mu \mathrm{l}$ to $104.10 \mathrm{ng} / \mu \mathrm{l}$. The purity of the samples ranged from 1.53 to 2.21 . The level of DNA purity is good if the OD260/OD280 ratio value ranges from 1.8 to 2.0 [15]. We have added RNase A during one of DNA extraction step.

A ratio or purity value above 2.0 indicates RNA contamination in the sample, while a ratio of less than 0.6 indicates protein in the sample [16]. Blood is a sample with a high RNA content [17]. However, we made sure this RNA contamination will not affect the characterization of the DNA band PCR results, because of the primers the primary 2550F2781R for the CHD gene was used. PCR with specific primers is based on the principle that the recombinant Taq DNA polymerase is more specific for 32 oligonucleotide primers that fully match the target gene. If the primers used fully match one allele genotype and the PCR process is carried out properly, then the sequence of bases that match the primary will be amplified, while the bases that do not match will not be amplified [18].

\subsection{DNA amplification}

PCR products were run in agarose gel. Electropherograms are below (Fig.1, Fig. 2 and Fig. 3). 


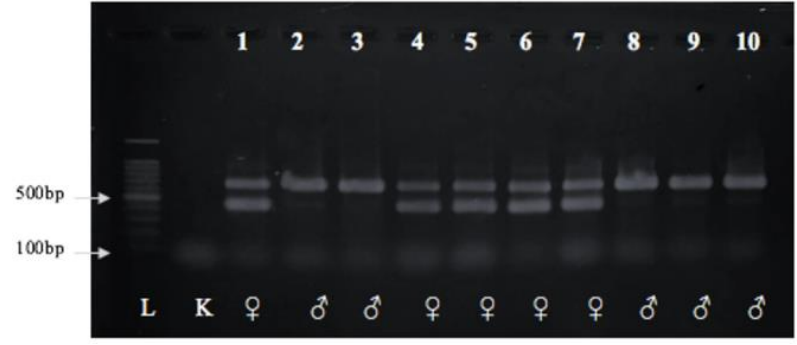

Fig 1. Electrophoregram Sample 1-10. $\mathrm{L}=100 \mathrm{bp}$ ladder, $\mathrm{K}=$ Negative control, 1=Seutia, $2=$ Datuk, $3=$ Samson, $4=$ Rojali, 5= Bambang, $6=$ Shima, $7=$ Gery, $8=$ Grace, $9=$ Doryis, $10=$ Paw.

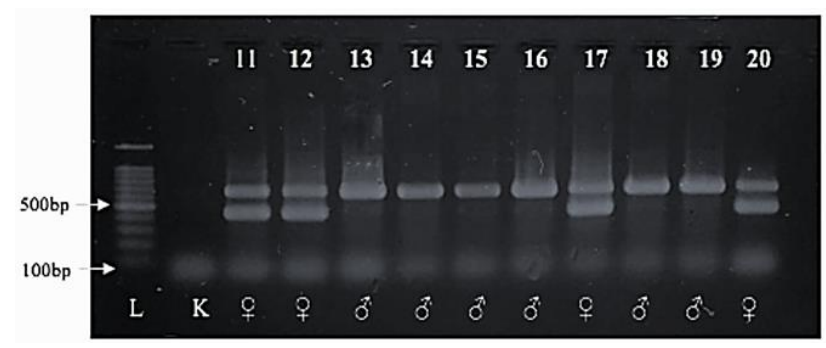

Fig 2. Electrophoregram Sample 11-20. $\mathrm{L}=100 \mathrm{bp}$ ladder, K $=$ Negative control, 11=Ambar, $12=$ Usro, $13=$ Roda , 14= Dani, 15= Rexa, 16= Tedy, 17= Dede, 18= Ujang Utuy, 19= Rama, 20= Langit.

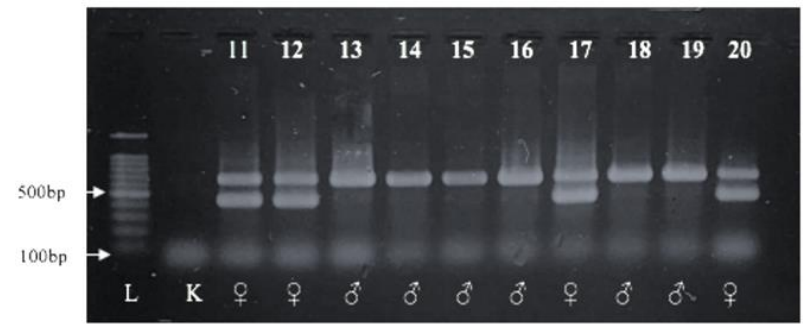

Fig 3. Electrophoregram Sample 21-30. $\mathrm{L}=100 \mathrm{bp}$ ladder, $\mathrm{K}$ $=$ Negative control, 21 $=$ Dita, $22=$ Nugie, $23=$ Lurah, 24= Jatim, 25= Elok, 26= Tom, 27= Tiko, 28=Kubo, 29= Jejen, $30=$ Caca

The length of the CHD-Z band ranged from $625 \mathrm{bp}$ to $781 \mathrm{bp}$ and for the CHD-W ranges from $427 \mathrm{bp}$ to 546 bp. The results of DNA amplification using a $2550 \mathrm{~F} /$ 2718R primer showed clear DNA bands, by forming two banding patterns for female and one banding pattern for male during the visualization process. This is in accordance with the research of [19] which identified the sex of the Changeable hawk-eagle and Javanese eagles. Primer $2550 \mathrm{~F} / 2718 \mathrm{R}$ is one of the primers showed results with a clear DNA band, with the length of DNA on the CHD-Z chromosomes 638-725 bp and CHD-W 372-640 bp. Despite having different base lengths, the 2550F / 2718R primers in the Sitohang study and this study showed DNA bands that were able to identify the sex of the Changeable hawk-eagle.

\subsection{Sex Ratio Gender}

The sex ratio female to male of all samples tested are as follows:

$$
R p=\frac{N_{\mathrm{FP}}}{N_{\mathrm{MP}}}=\frac{17}{13}
$$

The results of the total samples tested identified 17 females and 13 males. The sex ratio in the research results was the sex ratio of the Changeable hawk-eagle in the management area. Eagle is a monogamous animal or animal that is faithful to one partner in its life. Therefore, a good sex ratio for eagles is 1: 1 [20]. This ratio can be a consideration in the breeding program carried out by PKEK at the rehabilitation site. The breeding program is carried out by PKEK for several birds that are considered capable of being bred by hope to increase the number of individuals from these species [21].

Various types of breeding programs in captivity are used for preventing possible endangered populations. Most of these programs are to release additional individuals into the wild to support population increase in the conservation of a population. In small populations, it is important to increase population growth rapidly to avoid the allele effect. For example, in Falco naumanni, the number of female offspring is one of the limiting factors of population growth. It is possible to increase population growth by manipulating the sex ratios of offspring from the breeding program and producing sex ratios that have a higher reproductive limit [22]. It is hoped that the release of the eagles from the rehabilitation will produce new eaglet, so that the eagle population at the release location increases. An eagle that is about to be released is recommended in a paired state with hope can produce offspring from the pair. The pairing can be done to the young ones before release. However, it is hard to do for rehabilitated eagles that are adults (already had a previous partner).

This is also related to the ecological function of the wild eagle as a predator. The Changeable hawk-eagle is one-of-a-kind birds of prey that occupy the top consumer positions in the food web in the ecosystem. If there is a disruption to the population bird of prey, the balance in food web also will be disturbed. The eagle also becomes the indicator for healthy environment due to its sensitivity [23]. Apart from considering the sex ratio in release, the readiness of eagles must also be considered. The criteria and determinants of eligibility for release were analyzed by assessing the rehabilitated eagles' behavior including hunting, perching, flying and interaction [24].

\subsection{Comparison of Genotype and Morphological}

Morphometric data was taken from all eagles by PKEK when they were entering the rehabilitation place. These included data for sex determination. The classification was based on morphometric measurements i.e. body weight, body length, tail length, wing span, beak length, beak height, beak width, tarsus length, foot length and cloaca examination. The comparison between morphometrics and DNA sexing result from this research can been seen from Table 1 . 
Table 1. Comparison of Results of Gender Determination.

\begin{tabular}{|c|c|c|c|}
\hline No & Sample & $\begin{array}{l}\text { Morphometric } \\
\text { (Source: } \\
\text { PKEK) }\end{array}$ & $\begin{array}{l}\text { DNA sexing } \\
\text { (This research) }\end{array}$ \\
\hline 1 & Seutia & $\hat{0}$ & q \\
\hline 2 & Datuk & $\sigma^{1}$ & $\sigma^{\pi}$ \\
\hline 3 & Samson & $\hat{0}$ & $\hat{0}$ \\
\hline 4 & Rojali & 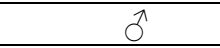 & 9 \\
\hline 5 & Bambang & 0 & q \\
\hline 6 & Shima & q & q \\
\hline 7 & Gery & 우 & q \\
\hline 8 & Grace & 웅 & $\hat{0}$ \\
\hline 9 & Doris & $\hat{0}$ & 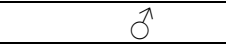 \\
\hline 10 & Paw & q & $\hat{0}$ \\
\hline 11 & Ambar & 운 & 운 \\
\hline 12 & Usro & $\hat{0}$ & q \\
\hline 13 & Roda & 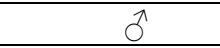 & $\hat{0}$ \\
\hline 14 & Dani & 0 & $\hat{0}$ \\
\hline 15 & Rexa & 0 & 0 \\
\hline 16 & Tedy & 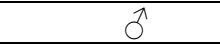 & $\hat{0}$ \\
\hline 17 & Dede & $\hat{0}$ & q \\
\hline 18 & $\begin{array}{c}\text { Ujang } \\
\text { utuy }\end{array}$ & $\sigma^{\lambda}$ & $\hat{\sigma}$ \\
\hline 19 & Rama & 0 & 0 \\
\hline 20 & Langit & $\hat{0}$ & q \\
\hline 21 & Dita & 오 & 운 \\
\hline 22 & Nugie & $\hat{0}$ & 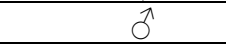 \\
\hline 23 & Lurah & 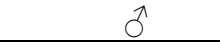 & q \\
\hline 24 & Jatim & 0 & 웅 \\
\hline 25 & Elok & 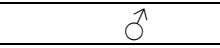 & 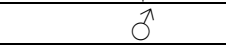 \\
\hline 26 & Tom & $0^{1}$ & 9 \\
\hline 27 & Tiko & 0 & 운 \\
\hline 28 & Kubo & $0^{1}$ & 9 \\
\hline 29 & Jejen & $\hat{0}$ & q \\
\hline 30 & Caca & 오 & q \\
\hline
\end{tabular}

Note: $\hat{\delta}=$ male; $\phi=$ female

PKEK data was obtained from morphometric and cloacal examination. The comparison of sex determination between morphometric and DNA sexing showed fourteen differences. Gender determination using polymorphic DNA analysis from blood or wing samples is almost $100 \%$ accurate and is the only method for definitive sex determination of birds [25]. The gender classification differences can be due to various factors. Correct labeling of samples and not being confused during processing is very important in determining the sex of all samples. In addition, the physical condition of birds for morphometric sex determination must be intact and without defects, either mild or permanent [26]. The eagle rehabilitated in PKEK is a confiscated or confiscated eagle, that is usually kept as a pet. Some of the eagles are in an incomplete state; like loss of primary wing feathers, deformed beaks, broken wings, broken legs, etc. Physical conditions greatly influence the results obtained from morphometric measurements.

A cloacal examination was also done by PKEK. Although cloaca examination is a method that is often used to determine the sex of monomorphic birds, this method has many disadvantages including: a. need an observer with experience sufficient; b. only possible during the breeding season for some species; c. can damage the internal parts of the bird due to the pressure applied during visualization of the penis [27].

The sexes classification of 37 individuals of Whitebellied sea-eagle using morphometric and genetic analyzes was done by [28]. The morphometric data use as a grouping reference are the length of the foot with the nails, the length of the tarsus, and the width of the wings. Genetic analysis is carried out using samples of blood, tissue and hair. Genetic analysis showed 100\% accuracy based on the results of the previously performed laparoscopic sexing. The morphometric method shows an accuracy of $92 \%$, with the error of grouping one female and two males.

Results of sex determination by DNA sexing markers shows more accurate results in several studies that have been done and in this study. This study obtained more accurate results with three repetitions of PCR which showed consistent results. Given the importance of knowing the correct gender prior to the release of rehabilitated eagles, it is hoped that this method can be used by the PKEK to determine the sex of the eagle that will be rehabilitated for conservation success.

\section{Conclusion}

The DNA sexing marker used in this research is proven to be reliable for gender detection in monomorphic Changeable hawk-eagle.

\section{Acknowledgment}

The authors sincerely thank the Pusat Konservasi Elang Kamojang (PKEK) for providing the samples and morphometric data.

\section{References}

1. Sukara, E. and I.S.L. Tobing. Vis Vitalis. 01, 6369 (2008)

2. Withaningsih, S., Parikesit, Iskandar, J. and Megantara, E.N. Biodiversitas. 18, 1234-1242 (2017).

3. MacKinnon, J., K. Philips, and B. van Balen, Seri Panduan Lapangan Burung-Burung di Sumatra, Jawa, Bali, dan Kalimantan. LIPI. Bogor. (1998).

4. Nugraha, C.S., Aktivitas Harian Elang Jawa (Spizaetus bartelsi Stresemann, 1924) pada Masa Rehabilitas di Pusat Konservasi Elang Kamojang. Laporan Kerja Praktek Fakultas Matematika dan Ilmu Pengetahuan Alam, Universitas Padjadjaran. Jatinangor. (2017). (Unpublished work).

5. Cerit, H. and K. Avanus, World's Poultry Science Journal. 63, 91-99 (2007)

6. Wedekind, C., Managing Population Sex Ratios in Conservation Practice: How and Why?, in Topics 
in Conservation Biology, T. Povilitis, Editor., IntechOpen. London. (2012).

7. Rudnick, J.A., Katzner, T. E., Bragin, E. A., Rhodes, O. E., Jr. and DeWoody, J.A. Mol Ecol. 14, 2959-67 (2005).

8. Reddy, A., P. Vibhu, and S. Shivaji, Curr. Sci., 2007. 92: p. 659-662.

9. Dubiec, A.. Biol. Lett. 43, 3-12 (2006).

10. Purwaningrum, M., Nugroho, H. A, Asvan, M. , Karyanti, K., Alviyanto, B., Kusuma, R. and Haryanto, A. Vet. World. 12, 1506-1513 (2019).

11. Fournier, A.M.V., Sheildcastle, M. C., Fries, A.C. and Bump, J. K. Wildl. Soc. Bull. 37, 881-886 (2013).

12. Fridolfsson, A.-K. and H. Ellegren. J. Avian Biol. 30, 16-121 (1999).

13. Lazar, I. and I. Lazar, Gel Analyzer 2010a: Freeware 1D gel electrophoresis image analysis software, 2010. http://www.gelanalyzer.com.

14. Skalski, J.R., K.E. Ryding, and J.J. Millspaugh, 10 - Integration of Analytical Techniques, in Wildlife Demography, J.R. Skalski, K.E. Ryding, and J.J. Millspaugh, Editors. Academic Press: Burlington. p. 541-564 (2005).

15. Sambrook, J. and D.W. Russell, Molecular Cloning: A Laboratory Manual. New York: Cold Spring Harbor, Cold Spring Harbor Laboratory Press. (1989).

16. Khare, P., Raj, V, Chandra, S. and Agarwal, S. J. Forensic Dent. Sci, 2014. 6, 81-85 (2014).

17. Shen, Y., Li, R., Tian, Fei, Chen, Z., Lu, N., Bai, Y., Ge, Q. and Lu, Z. Onco Targets and Ther. 11, 3573-3581 (2018).

18. Yang, R., Zhang, J.H. and. Yuan, G.Y.. Mol Med Rep. 7, 201-4 (2013).

19. Sitohang, L.R., Pramana, Y. and Mursyanti, E.. Skripsi. (2017).

20. Rudnick, J.A., Katzner, T. E., Bragin, E. A., Rhodes, O. E., Jr. and De Woody, J.A. Mol Ecol. 14, 2959-67 (2005).

21. PT. Pertamina Geothermal Energy Area Kamojang. Perlindungan Keanekaragaman Hayati. Keanekaragaman Hayati Pertamina Geothermal Energy Area Kamojang. Kamojang Jawa Barat. (2019).

22. Lenz, T.L., Jacob, A. and Wedekind, C. Anim. Conserv. 10, 236-244 (2007).

23. Prawiradilaga, D.M., Murate, T. , Muzakkir, A., Inoue, T, Kuswandono, Supriatna, A., Ekawati, D. , Afianto, M.Y., Hapsoro, Ozawa, T. and Sakaguchi, N. Panduan survei lapangan dan pemantauan burung-burung pemangsa. Biodiversity Conservation Project-JICA dan Taman Nasional Gunung Halimun-PHKA: Bogor (2003).

24. Ulumiyah, N. JPSL. 9, 337-351 (2019).

25. Naim, D.M., Nor, S.A.M. and Baharuddin, M.H. Genet. Mol. Res. 10, 2505-2510 (2011).
26. Rahmat, A., Pengukuran Karakter Morfometrik Pada Beberapa Burung Pemangsa Diurnal Di Pusat Penyelamatan Satwa Cikananga (PPSC). Laporan Kerja Praktek., Fakultas Matematika dan Ilmu Pengetahuan Alam, Universitas Padjadjaran.: Jatinangor. (2004)

27. Calabuig, C.P., Green, A.J., Ferrer, M., Muriel, R. and Moreira, H. Stud. Neotrop. Fauna Environ. 46, 177-184 (2011).

28. Shephard, J.M., Catterall, C.P. and Hughes, J.M. Emu. 104, 83-87 (2004).) 